BULLETIN OF THE HEGEL SOCIETY OF GREAT BRITAIN

Hegel and Kant No 33 


\section{HEGEL SOCIETY OF GREAT BRITAIN}

\section{OFFICERS}

Honorary President

Chairman

Secretary

Treasurer

Bulletin Editor

Members of the Council
Professor H S Harris

(York University, Toronto)

Professor Michael Petry

(Erasmus University, Rotterdam)

Professor Howard Williams

(University College of Wales, Aberystwyth)

Dr Gary K Browning

(Oxford Brookes University)

Dr Robert Stern

(University of Sheffield)

Professor Leon Pompa

(University of Birmingham)

Dr Bernard Cullen

(Queen's University, Belfast)

Professor Kenneth Westphal

(University of New Hampshire)

Dr Z A Pelczynski

(Pembroke College, Oxford)

Nicholas Walker

(Magdalene College, Cambridge) 


\author{
Editor: Robert Stern \\ Assistant Editors: Nicholas Walker, Katerina Deligiorgi \\ Production Manager: Sue Spence
}

This Bulletin is published by the Hegel Society of Great Britain and appears twice yearly (Spring/Summer and Autumn/Winter). It is free for members of the Society.

Subscription to non-members is the same as the normal subscription to the Society ( $£ 8$; f6 for students) and includes postage and second class mail in Britain and airmail to Europe. Library subscriptions are 1212 . Subscriptions outside Europe, which include airmail postage, are US\$17 (libraries \$24). Advertisements are welcome and should be submitted on A4 size paper. The charge is $\mathfrak{1 3 5}$ per page.

All correspondence concerning the Bulletin, including books for review, should be addressed to the Editor at the Department of Philosophy, University of Sheffield, Sheffield S10 2TN, England, UK.

All subscriptions should be sent to the Treasurer: Dr Gary Browning, School of Business/Politics, Oxford Brookes University, Gipsy Lane Campus, Headington, Oxford OX3 ODP. Cheques should be made payable to "The Hegel Society of Great Britain".

The copyright of material published in the Bulletin is retained by the individual authors.

The Hegel Society of Great Britain is affiliated to the Political Studies Association.

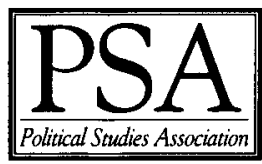




\section{BULLETIN OF THE HEGEL SOCIETY OF GREAT BRITAIN}

\section{No 33 Spring/Summer 1996}

\section{Hegel and Kant}

- McDowell's Kant: Mind and World

Graham Bird

- Kant, Hegel, and the Transcendental Material Conditions of Possible

Experience

Kenneth R Westphal

- In Defence of the Abstract

Philip Stratton-Lake

- The Reciprocity Thesis in Kant and Hegel

Alan Patten

- Beauties of Nature and Beauties of Art: On Kant and Hegel's Aesthetics

Giuseppina D'Oro

Harold E Crichlow

Conference Reports

Obituary

Duncan Forbes (1922-1994) 